defendants, and individual aliens as well, should eagerly embrace this opportunity to promote the administration of justice in international relations. By removing legal cases from the diplomatic to the judicial forum under the safeguards above-mentioned, both justice and peace are promoted.

EDwin M. Borchard.

\title{
FOOD SUPPLIES AND BELLIGERENTS
}

The publication of the volumes on the public relations of the Commission for Relief in Belgium is opportune. ${ }^{1}$ There are still problems in regard to immunities of noncombatant populations and property which have long been discussed. As early as 1781, Franklin wrote:

There are three employments which I wish the law of nations would protect, so that they should never be molested or interrupted by enemies even in time of war. I mean farmers, fishermen, and merchants, because their employments are not only innocent, but are for common subsistence and benefit of the human species in general. As men grow more enlightened, we may hope this will in time be the case. Till then we must submit, as well as we can, to the evils we can not remedy.

In 1907, Mr. Choate at the Second Hague Peace Conference made an elaborate argument upon the exemption from capture of private property at sea, supporting the traditional attitude of the United States on this contention as well as on the closely related doctrine, the freedom of the sea. Mr. Choate, referring to what were sometimes called "commerce destroyers," said:

The marked trend of naval warfare among all great maritime nations at the present time is to dispense with armed ships adapted to such service, and to concentrate their entire resources upon the construction of great battleships whose encounters with those of their adversaries shall decide any contest, thus confining war, as it should be, to a test of strength between the armed forces and the financial resources of the combatants on sea and land. ${ }^{3}$

When the question of exempting private property at sea came before the conference for vote, among the states voting in the negative were France, Great Britain, Japan and Russia.

During the World War the battleship was a factor, but the cutting off of the food supply by vessels of less tonnage was a main objective. There was also a question as to what constituted food, and the list of contraband was enlarged to an extent heretofore unknown, so that almost every commodity might be included. States mobilized their entire populations. It was difficult to determine whether women working in munition factories behind the lines were more essential or the men at the front. Some argued

1 See book-note in this Journas, January, 1930, p. 209.

2 Deuxieme Conférence Internationale de la Paix, Tome III, p. 777.

9 Sparks, Works of Franklin, p. 41. 
that to bring a belligerent to terms by shortage of food, for starvation is not necessary, is more humane than to attain the same result by killing of its men who were of an age and of sufficient physical and mental capacity to bear arms.

The doctrine of boycott as set forth in the Covenant of the League of Nations seems to rest for its effectiveness upon the cutting off of supplies. Supplies for noncombatant population furnished from the outside may release other supplies to the armed forces thus making possible the longer war. It is true that the question of supplies is connected with contraband, blockade, continuous voyage, freedom of the seas, and many other unsettled questions, and, therefore, with the problem of limitation of armament on land and sea and in the air.

The attempt to extend by analogy the methods and results of the work of the Commission for Relief in Belgium to general conduct of war would be misleading, as would be clear when the unusual character of the war in Belgium is considered. The documents show that Great Britain was often uncertain of the wisdom of the continuance of this work from a military point of view, but the argument was advanced that the noncombatant population of an ally was thereby kept from starvation. An organization such as the Commission for Relief in Belgium could not always be constituted. It had its own flag, negotiated with both belligerents and with neutrals, and the preface of the report on the commission's work states that a British Foreign Office official once described it "as a piratical state organized for benevolence." The documents show one man, Mr. Hoover, a man without responsibility to any one state, as in practical control and a commission in fact without legal existence. Manifestly the recurrence of the Belgian war status and the conditions following is not probable.

The furnishing of food supplies to noncombatant population would be a problem requiring the reopening of so many intricate questions in regard to the conduct of war that many of the treaties entered upon for the limiting of the effects of war might have to be reconsidered and new policies inaugurated. Mankind may yet have to wait, as Franklin said in 1781, till "men grow more enlightened."

Grorge Grafton Wilson. 